\title{
FORMATION OF THERMOBITUMEN FROM OIL SHALE BY LOW-TEMPERATURE PYROLYSIS IN AN AUTOCLAVE
}

\author{
L. TIIKMA ${ }^{(\mathrm{a})^{*}}$, A. ZAIDENTSAL ${ }^{(\mathrm{a})}$, M. TENSORER $^{(\mathrm{b})}$ \\ (a) Department of Oil Shale Technology \\ Tallinn University of Technology \\ 5 Ehitajate Rd., 19086 Tallinn, Estonia \\ (b) Départment de Chimie, \\ Université de La Rochelle Pole Sciences et Technologies \\ Avenue Michel Crépeau \\ 17042 La Rochelle cédex 01, France
}

\begin{abstract}
This work presents a review of investigations concerning formation of thermobitumen $(T B)$ and a systematic experimental study of thermobituminization of Baltic oil shale, Kukersite, in autoclaves. The bituminizing process was performed at different nominal temperatures $\left(340-380^{\circ} \mathrm{C}\right)$ and residence times (20 min-10 hours). Distribution of organic matter of the shale between thermobitumen, gas and insoluble in benzene solid residue was studied. Composition of thermobitumen depending on pyrolysis conditions was characterized. The pyrolysis process of kukersite in autoclaves consists of three stages: 1. Formation of TB and gas from kerogen until obtaining the maximum yield of TB. 2. Equilibrium of formation and thermal cleavage of TB molecules. The yield of TB is maximum and practically constant in this stage. The quantity of gas grows continously and that of organic solid residue is minimal. The lower is the temperature, the longer is the thermobituminization stage. 3. Destruction of obtained TB forming gas, coke and oil. The formed oil favors extraction of TB from solid residue, but a part of kerogen gets lost with coke. The duration of these stages depends on the nominal temperature being shorter at higher temperatures.
\end{abstract}

\section{Introduction}

The yield of shale oil obtained by pyrolysis of Baltic oil shale kukersite in industrial retorts is only $14-17 \%$, depending on the retort configuration and by-products of low calorific value, such as gas and semicoke. The semicoke is still sent to the landfills where it represents a hazardous industrial waste.

\footnotetext{
* Corresponding author: e-mail laine.tiikmaa@ttu.ee
} 
At laboratory retorting the organic matter $(\mathrm{OM})$ is distributed between $65.6 \%$ oil, $10.7 \%$ gases, $18.3 \%$ semicoke and $5.4 \%$ pyrolytic water [1]. A more complete application of OM of oil shale is topical considering both economical and ecological aspects.

One of the characteristics of kukersite causing considerable difficulties at industrial oil production is its bituminisation - transition to the plastic state within the temperature range of $350-400{ }^{\circ} \mathrm{C}$ at slow heating. The troublesome consequences such as sticking of organic matter to the retort walls, formation of hangings, etc. have been eliminated by going through the temperatures of maximum TB formation at a relatively high speed (not less than $\left.3-4{ }^{\circ} \mathrm{C} / \mathrm{min}\right)[2]$.

The most widespread oil shales of the world typically form paraffin-rich oil at their retorting. The content of oxygen-containing compounds, including phenols, in these oils is negligible or nil. Volatile products of kukersite decomposition are thermally unstable at the moment of their formation (e.g. oxygen-containing compounds, including high-boiling phenols), and they undergo a considerably more extensive secondary pyrolytic transformation as compared with other shales. As a result, the carbonaceous residue in semicoke is of secondary origin formed at pyrolysis of these unstable compounds.

Kukersite's OM (kerogen) contains less than $1 \%$ natural soluble bitumens [1]. The data on thermal transformation of OM have proved its low thermal stability, particularly in the temperature range between $275-300{ }^{\circ} \mathrm{C}$ at which up to $30-40 \%$ of the decomposition water from its whole potential under semicoking conditions is evolved [3]. At the same time, the splitting of other simple compounds like $\mathrm{CO}_{2}, \mathrm{CO}, \mathrm{H}_{2} \mathrm{~S}$, lower alkanes and alkenes is observed.

Klewer and Mauch [3] were the first scientists to study the temperature effect on the decomposition of kukersite. According to them, the main amount of destruction water is formed below $320{ }^{\circ} \mathrm{C}$ where the $\mathrm{OM}$ is destructed to volatile and soluble products and no coke is formed.

Aarna, Kask, Lippmaa, Shulman, Dobrjanski and others [2-20] have studied the formation of TB in open systems, only Kogerman and Karavayev [9] have carried out the process in autoclaves. Experiments were made varying heating time and pyrolysis temperature to study their influence on the yield and composition of oil and TB.

Kogerman [4] presented the pyrolysis of kukersite as a range of sequential processes as follows:

Below $150{ }^{\circ} \mathrm{C}-$ separation of water and occludive gases,

$170-180^{\circ} \mathrm{C}$ - beginning of kerogen destruction,

$320-340{ }^{\circ} \mathrm{C}-$ active destruction of kerogen, beginning of gas evolution in large quantities,

$380-390{ }^{\circ} \mathrm{C}-$ beginning of destruction of polymerization products forming liquid products (oil),

$415-420{ }^{\circ} \mathrm{C}$ - endothermic reactions of coke formation. 
Kogerman and Kopwillem [5] concluded that the yield of destruction water under the pressure 100 at is practically the same as that in open retorts and does not depend on pyrolysis atmosphere. So, kerogen should include unstable formations, possible aliphatic compounds, which transform to more stable structures emitting equal quantity of water which does not depend on pyrolysis atmosphere.

Kask and Aarna studied the yield and composition of products depending on pyrolysis conditions in Fischer retort [11-13,16], obtained data are given in Table 1.

Table 1. Yield and elemental composition of products obtained from kukersite by Kask [11, 12]

\begin{tabular}{|c|c|c|c|c|c|c|c|}
\hline \multirow[t]{2}{*}{ Species } & \multirow{2}{*}{$\begin{array}{c}\text { Yield, } \\
\% \\
\text { TB/OM }\end{array}$} & \multicolumn{4}{|c|}{ Elemental composition, $\%$} & \multirow[t]{2}{*}{$\mathrm{H} / \mathrm{C}$} & \multirow{2}{*}{$\begin{array}{c}\text { Molec. } \\
\text { mass }\end{array}$} \\
\hline & & $\mathrm{C}$ & $\mathrm{H}$ & $\mathrm{S}$ & $\mathrm{O}+\mathrm{N}$ & & \\
\hline $\begin{array}{l}\text { Initial concentrated shale, } \\
\quad(87.25 \% \text { OM from shale })\end{array}$ & & 82.1 & 10.63 & 0.75 & 6.5 & 1.55 . & \\
\hline TB $275^{\circ} \mathrm{C}, 456 \mathrm{~h}$ & 17.9 & 83.0 & 10.1 & 0.50 & 6.7 & 1.46 & 710 \\
\hline TB $300{ }^{\circ} \mathrm{C}, 387 \mathrm{~h}$ & 69.8 & 85.1 & 8.77 & 0.32 & 5.8 & 1.24 & 1300 \\
\hline TB $340{ }^{\circ} \mathrm{C}, 12 \mathrm{~h}$ & 59.8 & 83.8 & 9.78 & 0.52 & 5.9 & 1.40 & 1240 \\
\hline TB $360{ }^{\circ} \mathrm{C}, 4 \mathrm{~h}$ & 63.8 & 83.6 & 9.56 & 0.50 & 6.3 & 1.37 & 790 \\
\hline TB $380^{\circ} \mathrm{C}, 4 \mathrm{~h}$ & 35.6 & 85.3 & 8.85 & 0.53 & 5.3 & 1.25 & 651 \\
\hline $\begin{array}{l}\text { Organic residue insoluble } \\
\text { in benzene }\left(360{ }^{\circ} \mathrm{C}, 5 \mathrm{~h}\right)\end{array}$ & 1.1 & 83.3 & 10.43 & 0.35 & 5.9 & 1.50 & \\
\hline
\end{tabular}

Schulman reported [14] that the maximum yield of TB was obtained at the temperature range $390-395^{\circ} \mathrm{C}$, and $\mathrm{TB}$ was made up to $55-57 \%$ of organic matter irrespective of oil shale quality. At these temperatures carbon content of organic solid residue (remained after extraction of TB with a mixture of ethanol-benzene) was of the minimum value.

Lille [7] gave the model of kukersite kerogen with the empirical formula $\mathrm{C}_{421} \mathrm{H}_{638} \mathrm{O}_{44} \mathrm{~S}_{4} \mathrm{NCl}$, according to which the elemental composition of kerogen should be, \%: $\mathrm{C}-76.9 ; \mathrm{H}-9.7 ; \mathrm{O}-10.7 ; \mathrm{S}-1.9 ; \mathrm{N}-0.2 ; \mathrm{Cl}-0.5$, and the atomic ratio of $\mathrm{H} / \mathrm{C} 1.515$. According to the last studies by NMR, macromolecule of kerogen is highly aliphatic, with the ratio of aliphatic to aromatic carbons $\mathrm{ca} 4-5$.

Aarna, Kask and Luts came to the conclusion that TB contains less hydrogen than initial kerogen $[6,7,10,13]$. On the basis of elemental composition, Luts [6] gave the empirical formula of kerogen as $\mathrm{C}_{7} \mathrm{H}_{10} \mathrm{O}$ and TB as $\mathrm{C}_{65} \mathrm{H}_{88} \mathrm{O}_{4}$ with the atomic ratio of $\mathrm{H} / \mathrm{C} 1.43$ and 1.35 , respectively. According to Kask [16], the formula of TB is $\mathrm{C}_{54.8} \mathrm{H}_{69.4} \mathrm{O}_{3}$ with atomic ratio of $\mathrm{H} / \mathrm{C} 1.27$ only. Thus, along with the loss of oxygen with water formation, and that of sulfur with $\mathrm{H}_{2} \mathrm{~S}$, also the loss of hydrogen occurs in the TB formation process. TB, formed in an open system under atmospheric pressure is a new formation which contains less both oxygen and hydrogen. At the first stage, the loss of hydrogen takes place due to emission of water 
and hydrogen sulfide. The main part of oxygen leaves with carbon dioxide. The oxygen, which is more strongly attached to carbon, remains in solid residue. The higher is the destruction degree, the less is the hydrogen content of $\mathrm{TB}$, and the more stable is the oxygen remained. Decreasing of hydrogen content of $\mathrm{TB}$, compared with that of kerogen, is more obvious if to take into account that at the first stage of thermal stabilization of $\mathrm{OM}$ the carbon is lost only as carbon dioxide.

Karavayev and Wener studied TB formation in an autoclave at the temperature range $350-360{ }^{\circ} \mathrm{C}$ and residence time $6-8$ hours [9]. The yield of TB soluble in benzene was $71.3 \%$, on kerogen basis, the yield of gas over $4 \%$, and its composition was as follows: $\mathrm{CO}_{2}+\mathrm{H}_{2} \mathrm{O}(41.5 \%), \mathrm{C}_{\mathrm{n}} \mathrm{H}_{2 \mathrm{n}}(2.0 \%)$, $\mathrm{CO}(1.8 \%), \mathrm{H}_{2}(13.2 \%), \mathrm{C}_{\mathrm{n}} \mathrm{H}_{2 \mathrm{n}+2}(41.5 \%)$. So, the gas consisted mainly of saturated hydrocarbons and hydrogen. The oil, which in autoclaves remains together with TB, may be enriched with hydrogen because it is a product of continual destruction and intermolecular reforming of TB. At the same time, a part of primary products of complicated structure should lose the hydrogen and form an insoluble residue. Atomic $\mathrm{H} / \mathrm{C}$ ratio in the process of $\mathrm{TB}$ formation was as follows: initial kerogen 1.46, TB 1.28, oil soluble in alcohol 1.35, TB insoluble in alcohol 1.14.

Kask [11,12] showed that TB is miscellaneous consisting of various molecules which can be divided by solvents into fractions of different molecular mass and properties. It has been proved [12] that when TB is subjected to carbonization, the yield of oil is less than by direct semicoking of oil shale. For example, the yield of oil from kerogen at retorting of the initial shale was $66.0 \%$, but at the two-stage carbonization of oil shale the yield of oil was only $56.9 \%$ (including $17.5 \%$ in the process of TB formation, $36.2 \%$ from retorting of separated TB and 3.2\% from semicoking of the residue insoluble in benzene). The total yield of the solid residue increased from 17.9 to $25.6 \%$, respectively. At the same time, the quantity of gas was practically constant (10.3 and $10.7 \%)$. The more complete was the low-temperature destruction of kerogen to $\mathrm{TB}$, the more structures in $\mathrm{TB}$ appeared to be able to condensate and coke during further carbonization, and the less the material remains which could be destructed to volatiles.

TB obtained in an open system has been characterized by molecular mass, elemental composition [3-16], solvent fractionation [11, 18], infrared spectroscopy [17, 18], and NMR spectroscopy [19]. It was shown [3-16] that molecular mass and elemental composition of TB depend on bituminisation conditions. In the composition of $\mathrm{TB}$ were found various polycyclic compounds of different molecular mass (average 400-500) connected together by oxygen links [11]. The molecule mass of TB obtained in autoclave was about 350 [9]. At the first stage of bituminization the content of carbon in TB is approximately $82 \%$ and that of hydrogen about $10 \%$. At higher temperatures and longer residence time the content of carbon increases and that of hydrogen decreases. Under more rigid conditions of bituminisation as a result of hydrogen redividing a part of TB becomes so 
poor in hydrogen that forms insoluble in benzene coke together with mineral part. The content of oxygen in TB is about $7 \%$, and it does not depend on temperature but depends on residence time. At a longer process the oxygen content decreases, reaching 5\%.

TB is a chemically active intermediate product, whose composition changes at storage.

The formation of TB as an intermediate pyrolysis state in the temperature range $375-425^{\circ} \mathrm{C}$ has been described also to be typical of USA oil shale [20]. Its properties (hydrogen-to-carbon ratios, carbon aromaticity, molecular mass) vary with time and temperature of pyrolysis and depend on the original kerogen structure. Comparative characterization of the Green River shale oil, heavy petroleum oil and oil sand bitumen based on their polarity is given in [21]. Shale oil contains some $\alpha$-olefins produced by cracking of hydrocarbon chain. IR spectra showed the presence of $\mathrm{C}=\mathrm{O}$, $-\mathrm{NH}_{2},-\mathrm{OH}$ groups. The presence of asphaltenes was also asserted.

Chemical composition of TB from kukersite was studied by Karavajev [9], Aarna, Lippmaa [10] and Kask [16]. For determination of functional groups, elemental analysis and chemical methods had been used. The occurrence of carboxyl, hydroxyl, carbonyl, methoxyl and ether groups had been studied. It was elucidated that TB consists mainly of oxygen-containing compounds including functional groups such as hydroxyl, carbonyl and ether. The share of the carbonyl group was small, including only $2 \%$ of total oxygen. It was established that beyond half of the elemental carbon is included into aromatic nucleus. To compare the composition of TB obtained in open or closed systems, the one from Fischer retort contains less oxygen and its molecular mass is greater. TB from autoclave contains also oil.

The above review concerning formation of $\mathrm{TB}$ evidences that the studies made preferably in open systems have been carried out about 50 years ago.

The aim of this work was to establish the conditions for kukersite pyrolysis in autoclaves that enable the most complete transformation of its kerogen to TB soluble in benzene. The experimental study of the bituminization process of kukersite was conducted in autoclaves at different temperatures and residence times. The dependence of material balances of the products and TB composition on pyrolysis conditions is described.

\section{Experimental}

\section{Materials and methods}

Air-dry, finely powdered $(0.04-0.1 \mathrm{~mm})$ kukersite, containing $0.8 \%$ moisture and $50.5 \%$ dry organic matter, was used. 20 -ml micro-autoclaves were charged with $4.0 \mathrm{~g}$ oil shale, weighed, and placed into a muffle oven with a constant nominal temperature $\left(340-380{ }^{\circ} \mathrm{C}\right)$. The residence time (from placing the autoclaves into oven) was varied from 20 min till 10 hours. The mass of gas formed was determined by the weight loss after discharging. 
The thermobitumen and the formed oil were extracted exhaustively with boiling benzene in a Soxhlet extractor. The mass of insoluble in benzene residue was dried at $105-110{ }^{\circ} \mathrm{C}$. The percentage of organic matter in kukersite and residues was estimated by burning out the mass at $825^{\circ} \mathrm{C}$ from the acid-treated and dried residues. The solvent benzene was removed from TB in a vacuum rotation evaporator at $60-70{ }^{\circ} \mathrm{C}$ and after that keeping the flask in a drying oven at $80^{\circ} \mathrm{C}$ during an hour. As noted in [11], removal of benzene traces from TB has been problematic work. The quantity of TB can be a little underestimated due to evaporation of low-boiling destruction products, or overestimated in the case a part of benzene, connected with TB by H-bonds, is not removed. According to the second approach, the mass of TB was found substracting the mass of gas and solid residue from the initial mass of oil shale. In this case the result can be overestimated due to admixture of the decomposition water.

The elemental composition of the TB was estimated with "Costech" analyzer. The functional group composition was investigated by FTIRspectroscopy "Interspec 2020". The group composition was determined by thin-layer chromatography (TLC). The content of maltenes in TB was found by exhaustive extraction of TB with $n$-hexane in Soxhlet extractor.

\section{Results and discussion}

\section{The dependence of TB yield on bituminization temperature and residence time}

The thermobituminization experiments with kukersite in autoclave were carried out at different temperatures $\left(340-380{ }^{\circ} \mathrm{C}\right)$ and residence times from 20 min to 10 hours. The results are given in Fig. 1.

Figure 1 demonstrates that pyrolysis process of kukersite in autoclaves consists of 3 stages:

1) Heating of shale till plastic condition and formation of TB and gas from OM. The quantities of TB and gases increase until the maximum yield of TB. At shorter residence times organic solid residue consists of undestructed $\mathrm{OM}$ and $\mathrm{TB}$ with high-molecular mass insoluble in benzene;

2) An equilibrium between formation and cleavage of TB. The yield of TB is maximum (up to $90 \%$ from OM of the initial shale) and practically constant. The quantity of gas is growing and organic solid residue is minimal. The lower the temperature, the longer the steady-state stage.

3) Further destruction of obtained TB to gas, coke and oil. The oil formed makes TB more easily extractable from the solid residue but a part of OM is lost with coke.

The length of these stages depends on temperature and is shorter at higher temperatures. 
a)

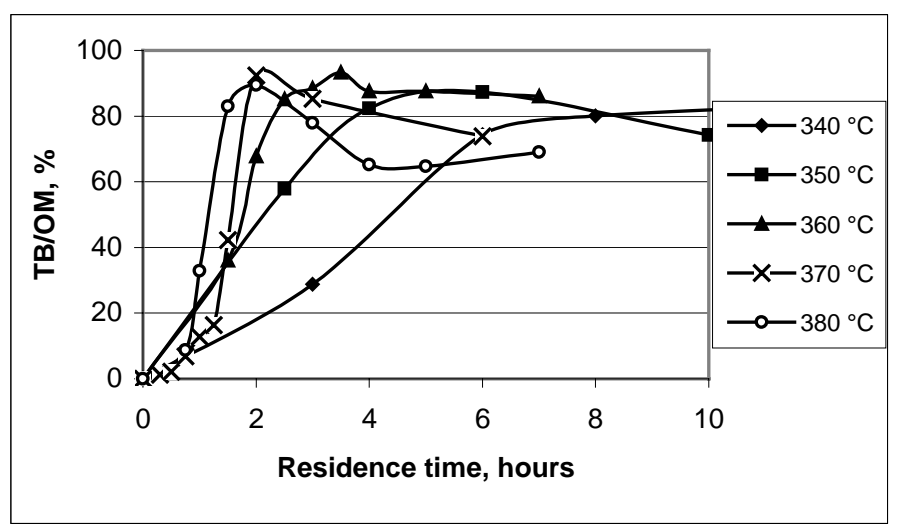

b)

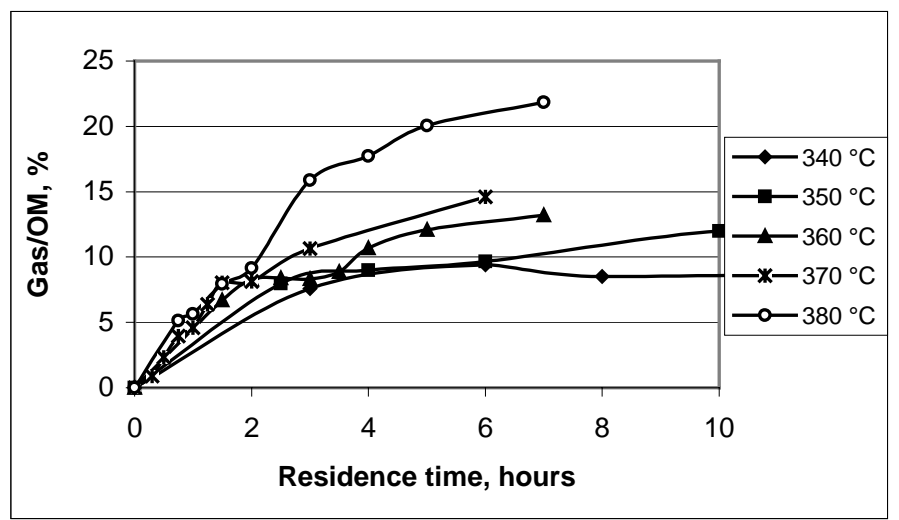

c)

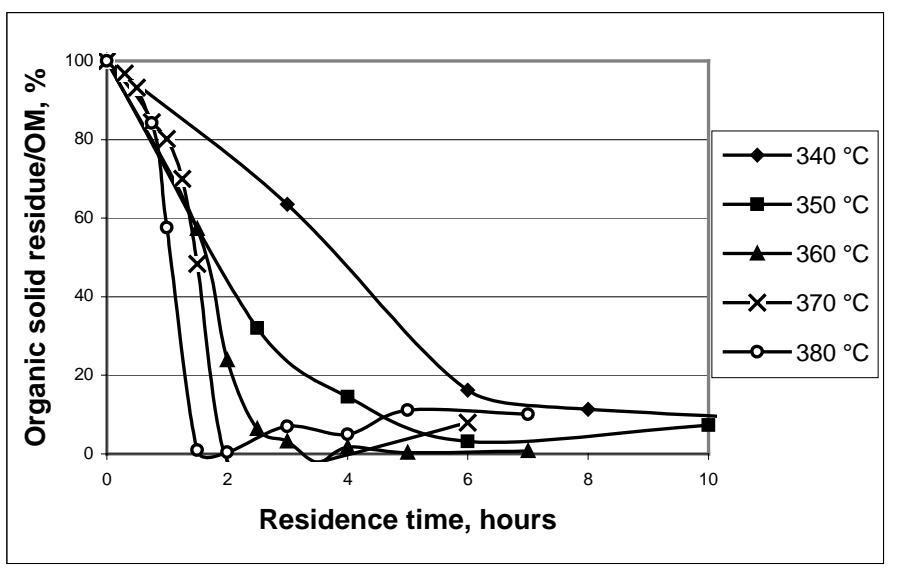

Fig. 1. Effect of time on the distribution of initial OM between TB (a), gas (b) and organic solid residue (c) at different nominal temperatures, ${ }^{\circ} \mathrm{C}$. 


\section{The composition of TB}

The composition of TB was characterized by its part soluble in hexane, maltenes (Table 2).

Table 2. The content of maltenes in TB (obtained at $380{ }^{\circ} \mathrm{C}$ ) depending on residence time

\begin{tabular}{|c|c|c|c|}
\hline Residence time & TB/OM, $\%$ & Maltenes/TB, $\%$ & Maltenes/OM, $\%$ \\
\hline $45 \mathrm{~min}$ & 8.8 & 61.7 & 5.4 \\
1 hour & 32.9 & 36.1 & 11.9 \\
2 hours & 87.7 & 45.25 & 40.5 \\
5 hours & 64.7 & 66.6 & 43.1 \\
\hline
\end{tabular}

It can be seen from Table 2 that at a short pyrolysis time when the quantity of TB is small, the share of maltenes is great - it is in accordance with the results of Aarna [8] according to which light destruction products are formed at the beginning of TB formation.

For comparison, the elemental composition of the initial kerogen, TB obtained in this work, natural bitumens from kukersite and industrial semicoking oil from open-system retorts are given in Table 3.

Table 3. Elemental composition of different organic species from kukersite OM

\begin{tabular}{|c|c|c|c|c|c|c|c|}
\hline & \multirow{2}{*}{$\begin{array}{c}\text { Yield, } \\
\text { kerogen } \\
\text { basis, \% }\end{array}$} & \multicolumn{5}{|c|}{ Elemental composition, $\%$} & \multirow[t]{2}{*}{$\mathrm{H} / \mathrm{C}$} \\
\hline & & $\mathrm{C}$ & $\mathrm{H}$ & $\mathrm{S}$ & $\mathrm{N}$ & $\begin{array}{c}\mathrm{O} \\
\text { (by difference) }\end{array}$ & \\
\hline Initial kerogen [7] & 100 & 77.3 & 9.8 & 1.7 & 0.4 & 10.8 & 1.52 \\
\hline Retort oil [1] & 65.6 & 83.0 & 9.9 & 1.1 & 0.1 & 5.9 & 1.43 \\
\hline TB $360^{\circ} \mathrm{C}, 3 \mathrm{~h}$, autoclave & 89.6 & 83.4 & 9.0 & 0.8 & 0.8 & 6.0 & 1.29 \\
\hline TB $360^{\circ} \mathrm{C}, 4 \mathrm{~h}$, retort $[10]$ & 63.8 & 83.6 & 9.6 & 0.5 & & 6.3 & 1.38 \\
\hline Natural bitumoids [1] & 0.71 & 71.8 & 10.5 & - & 0.5 & 17.2 & 1.75 \\
\hline
\end{tabular}

Table 3 demonstrates that the high yield of OM from kerogen obtained by extraction of TB under its optimum low-temperatures pyrolysis conditions is contributed by low $\mathrm{H} / \mathrm{C}$ ratio.

The elemental composition of $\mathrm{TB}$ obtained at $360^{\circ} \mathrm{C}$ at different residence times is given in Table 4.

Table 4. Dependence of elemental composition of $\mathrm{TB}$ on residence time $\left(360{ }^{\circ} \mathrm{C}\right)$

\begin{tabular}{|c|c|c|c|c|c|c|c|}
\hline \multirow{2}{*}{$\begin{array}{c}\text { Time, } \\
\mathrm{h}\end{array}$} & \multirow{2}{*}{$\begin{array}{c}\text { Yield, } \\
\%\end{array}$} & \multicolumn{5}{|c|}{ Elemental composition, $\%$} & \multirow[t]{2}{*}{$\mathrm{H} / \mathrm{C}$} \\
\hline & & $\mathrm{C}$ & $\mathrm{H}$ & $S$ & $\mathrm{~N}$ & $\mathrm{O}$ (by difference) & \\
\hline 1.5 & 36.0 & 78.5 & 9.5 & 0.9 & $<0.75$ & 10.2 & 1.45 \\
\hline 2 & 53.6 & 81.4 & 9.2 & 0.9 & $<0.75$ & 7.7 & 1.36 \\
\hline 3 & 89.6 & 83.4 & 9.0 & 0.8 & $<0.75$ & 6.0 & 1.29 \\
\hline 5 & 83.0 & 84.8 & 8.6 & 0.7 & $<0.75$ & 5.1 & 1.22 \\
\hline
\end{tabular}


At retorting, the elemental composition of TB did not depend on temperature but on depth of thermolysis [11], beginning with $82 \%$ carbon, $10 \%$ hydrogen and $7 \%$ oxygen at low rate of thermolysis, while at higher rates the content of carbon increased at simultaneous decrease of hydrogen and oxygen content. The elemental composition of TB obtained in autoclave at optimum residence time for every temperature, having minimal quantity of coke, could vary only due to differences in quantity of emitting gases. As the last was not considerable (Fig. 1b), TB composition should differ not much.

The chemical group composition of commercial retort oil from oil shale processing factory, TB, and maltenes from TB are given in Table 5.

Table 5. Chemical group composition of different species of shale oil by TLC, wt.\%

\begin{tabular}{|l|c|c|c|}
\hline Compounds & Retort oil [22] & TB $360^{\circ} \mathrm{C}, 3 \mathrm{~h}$ & Maltenes \\
\hline Aliphatic hydrocarbons & 11.1 & 3.7 & 5.8 \\
Monocyclic aromatic hydrocarbons & 5.4 & 2.0 & 2.5 \\
Polycyclic aromatic hydrocarbons & 23.1 & 4.3 & 20.2 \\
Neutral oxygen compounds & 16.7 & 9.3 & 22.3 \\
High polar compounds & 43.7 & 80.7 & 49.2 \\
\hline
\end{tabular}

The composition of soluble in hexane maltenes obtained in this work using an autoclave is similar to that of an industrial retort oil containing less high-polar compounds than TB. Low amounts of aliphatic and monocyclic hydrocarbons in TB express that the product requires further upgrading for being suitable as a liquid, especially as motor fuels.

Ratio of total alkenes to alkanes in aliphatic hydrocarbons was 0.86:1.

The composition of the hydrocarbons determined by GC is given in Table 6.

Table 6. Composition of alkenes and alkanes, wt.\%

\begin{tabular}{|c|c|c|}
\hline $\begin{array}{c}\text { Number of C } \\
\text { atoms }\end{array}$ & Alkenes & Alkanes \\
\hline 11 & 0.5 & - \\
12 & 0.8 & 0.7 \\
13 & - & 9.2 \\
14 & 11.8 & 8.9 \\
15 & 2.3 & 13.2 \\
16 & 36.3 & 26.4 \\
17 & 2.5 & 17.7 \\
18 & 23.3 & 12.4 \\
19 & 3.2 & 7.6 \\
20 & 13.1 & 2.4 \\
21 & - & - \\
22 & 5.0 & 1.5 \\
23 & - & - \\
24 & 1.2 & - \\
\hline
\end{tabular}


It is known [23] that olefins $\mathrm{C}_{13}-\mathrm{C}_{17}$ form at the beginning of kukersite destruction, that was explained by instability of isostructures, compared with the normal ones. The same tendency was discovered in the composition of maltenes from TB.

The composition of functional groups typical of maltenes and asphaltenes was investigated using infrared spectroscopic (IRS) method. The infrared spectra are presented in Fig. 2. Visible adsorptions are qualitatively similar, and differences between these two objects can be seen only in quantitative characters of hydrogen substituents in aromatic nucleus. IRS confirm the presence of benzene nucleus at 1600 and $1500-1515 \mathrm{~cm}^{-1}$. The substituents are bound in different positions of benzene nucleus. The absorption typical of methyl, methylene and methyne groups in alkyl chains appears at 3000 $2800,1400-1300$ and at $725 \mathrm{~cm}^{-1}$. Absorptions at 2960, 2872, 1460 and $1380 \mathrm{~cm}^{-1}$ caused by $\mathrm{CH}_{3}$ groups in different positions as well as those at 2930,2860 and $790-720 \mathrm{~cm}^{-1}\left(\mathrm{CH}_{2}\right.$ groups) are considerable. The most of methylene and methyne groups are bound to form different ring structures such as cyclic hydrocarbons and aromatic compounds. The peak at $1150 \mathrm{~cm}^{-1}$ refers to oxygen-carbon bond in the phenol molecule. The absorption in the region $1400-1470 \mathrm{~cm}^{-1}$ belongs to hydrogen in the $\mathrm{CH}_{2}$ and $\mathrm{CH}_{3}$ groups of aliphatic structures. Peaks in the region $2850-3000 \mathrm{~cm}^{-1}$ belong to alkanes, which are present in both maltenes and asphaltenes. $\mathrm{C}=\mathrm{O}$-containing compounds with the absorption maximum at $1700 \mathrm{~cm}^{-1}$ are clearly distinguishable.

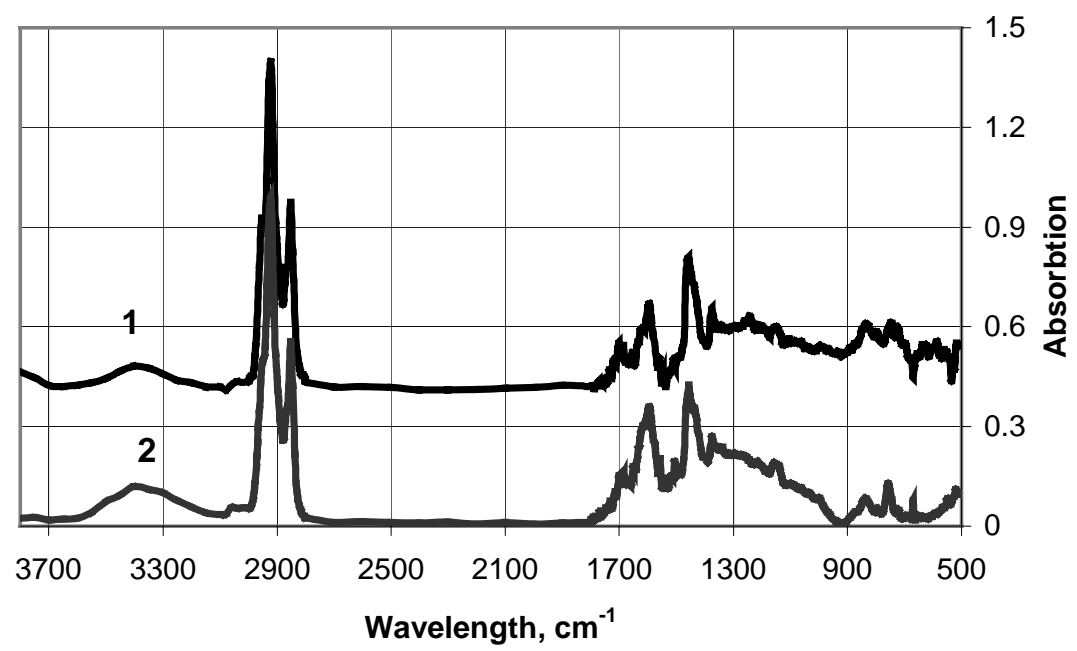

Fig. 2. FTIR spectra of maltenes (1) and asphaltenes (2) from TB obtained at $360{ }^{\circ} \mathrm{C}, 3$ hours. 


\section{Conclusions}

Experimental sudy of TB formation by low-temperature pyrolysis of kukersite in autoclaves was carried out, and the initial data for calculation of kinetics of kerogen thermobituminization were obtained. Material balances of the pyrolysis products under different pyrolysis conditions were obtained. The residence time for the highest yield of TB and that of the lowest content of insoluble in benzene coke was found for every pyrolysis temperature. The lower the temperature, the longer the steady-state stage during which up to $90 \%$ of TB from OM of the initial kukersite was achieved. The composition of TB was characterized by elemental analysis, content of maltenes (soluble in hexane) and asphaltenes and their chemical composition by TLC and IRS. It was found that $90 \%$ of $\mathrm{TB}$ and $72 \%$ of its maltenes consist of oxygencontaining compounds.

It was found that separation of TB from solid residue is a rather slow (laborious) process requiring extraction with a boiling solvent. Process of TB separation and its hydrogenation to meet the requirements of liquid fuels needs further elaboration.

\section{REFERENCES}

1. Urov, K., Sumberg, A. Characteristics of oil shales and shale-like rocks of known deposits and outcrops // Oil Shale. 1999. Vol. 16, No. 3. P. 1-64.

2. Jefimov, V., Purre, T. Characteristics of kukersite oil shale, some regularities and features of its retorting // Oil Shale. 1993. Vol. 10, No. 4. P. 313-319.

3. Klewer, H. W., Mauch, K. Über den estlandischen Ölschiefer "Kukersit". Halle, 1927.

4. Kogerman, P., Luts, K., Hüsse, J. The chemistry of Estonian oil shale. - M.-L: Goshimizdat, 1934 [in Russian].

5. Kogerman, P. N., Kopwillem, J.J. Hydrogenation of Estonian oil shale and shale oil // Inst. Petrol. Technol. 1932. Vol. 18, No. 108. P. 833-845.

6. Luts, $K$. Der estländische Brennschiefer Kukersit, seine Chemie, Technologie and Analyse. - Reval, 1934.

7. Lille, Ü., Heinmaa, I., Pehk, T. Molecular model of Estonian kukersite kerogen as evaluated by ${ }^{13} \mathrm{C}$ MAS NMR spectroscopy // Fuel. 2003. Vol. 82, No. 7. P. 799-804.

8. Aarna, A. Y. Isothermal destruction of Baltic oil shale // Transactions of Tallinn Polytechnic Institute. Series A. 1954. No. 57. P. 32-34 [in Russian].

9. Karavayev, N. M., Wener, I. M. About thermobitum of Gdov oil shale // Transactions of the Institute of Goryuchih Iskopayemyh. Academy of Sciences of SSSR. 1950. Vol. 2. P. 285-295 [in Russian].

10. Aarna, A. Y., Lippmaa, E. T. Thermal destruction of oil shale-kukersite // Transactions of Tallinn Polytechnic Institute. Series A. 1958. No. 97. P. 3-27 [in Russian].

11. Kask, K. A. About bituminizing of kerogen of oil shale-kukersite. Report I// Transactions of Tallinn Polytechnic Institute. Series A. 1955. No. 63. P. 51-64 [in Russian]. 
12. Kask, K. A. About bituminizing of kerogen of oil shale-kukersite. Report II // Transactions of Tallinn Polytechnic Institute. Series A. 1956. No. 73. P. 23-40 [in Russian].

13. Aarna, A. Y. Dynamic of separation of volatile products at thermal destruction of oil shale // Transactions of Tallinn Polytechnic Institute. Series A. 1955. No. 63. P. 65-81 [in Russian].

14. Schulman, A. I. Investigation of bituminizing process of shale organic concentrate. Thesis of PhD. Leningrad: VNIINeftehim, 1968 [in Russian].

15. Fomina, A. S., Pobul, L. Y., Degteryova, Z. A. Origin of kerogen of Baltic oil shale and its chemical characteristics as raw material. - Tallinn: Acad. Sci. Estonian SSR, 1965 [in Russian].

16. Kask, K. A., Mihkelson, V.J. The chemical composition of thermobitumen of kukersite oil shale // Transactions of Tallinn Polytechnic Institute. Series A. 1958. No. 97. P. 68-84 [in Russian].

17. Aarna, A., Alev, M. Investigation of low-temperature destruction of kukersite shale by infrared spectroscopy // Transactions of Tallinn Polytechnic Institute. Series A. 1964. No. 210. P. 3-14 [in Russian].

18. Broi-Karre, G., Proskuryakov, V. Investigation of low-temperature destruction of Gdov oil shale concentrate by infrared spectroscopy // J. Appl. Chem. 1966. Vol. 39, No. 5. P. 1214-1216 [in Russian].

19. Lille, $\ddot{U}$., Pehk, T., Purre, T., Bitter, L. Examination of the structure of heavy shale oil by means of NMR spectroscopy // Proc. Acad. Sci. ESSR. Chem. 1973. Vol. 22, No 1. P. 17-25 [in Russian with English summary].

20. Miknis, F. P., Turner, T. F., Berdan, G. L., Conn, P. J. Formation of soluble products from thermal decomposition of Colorado and Kentucky oil shales // Energy \& Fuels. 1987. Vol. 1, No. 6. P. 477-483.

21. Sadeghi, K. M., Sadeghi, M-A., Wen Hui Wu, Teh Fu Yen. Fractionation of various heavy oils and bitumen for characterization based on polarity // Fuel. 1989. Vol. 68, No. 6. P. 782-787.

22. Luik, H., Vink, N., Lindaru, E. Upgrading of Estonian shale oil. 1. Effect of hydrogenation on the chemical composition of kukersite retort oil // Oil Shale. 1996. Vol. 13, No. 1. P. 13-19.

23. Kuningas, K., Urov, K., Rang, S., Eisen, $O$. On the sequence of formation of aliphatic hydrocarbons during the thermal decomposition of the kukersiteshale // Proc. Acad. Sci. ESSR. Chem. 1977. Vol. 26, No. 2. P. 152-154 [in Russian].

Presented by J. Soone

Received June 19, 2007 